\title{
Informal Science Experiences among Urban and Rural Youth: Exploring Differences at the Intersections of Socioeconomic Status, Gender and Ethnicity
}

\author{
Patricia Wonch Hill', Julia McQuillan², Eileen A. Hebets ${ }^{3}$, Amy N. Spiegel'1, and Judy Diamond ${ }^{4}$ \\ ${ }^{1}$ Methodology and Evaluation Research Core Facility, University of Nebraska - Lincoln, Lincoln, NE; '2Department of Sociology, University of Nebraska - Lincoln, \\ Lincoln, NE; ${ }^{3}$ School of Biological Sciences, University of Nebraska - Lincoln, Lincoln, NE; ${ }^{4}$ University of Nebraska State Museum, University of Nebraska - Lincoln, \\ Lincoln, NE
}

Keywords: Middle School, Needs Assessment, Rural, Urban, Inequality, Adolescence

Publication Date: December 19, 2018

DOI: https://doi.org/10.15695/jstem/v1i1.28

\begin{abstract}
The current study explores patterns of informal science experiences among youth in urban and rural middle schools by gender and socioeconomic status. Data come from surveys in two Midwestern middle schools, one in a mid-sized city, and the other in a rural-remote town. We asked about participation in informal science activities (e.g. visiting zoos or museums, or watching shows about science) and if youth had participated in science-focused clubs in the last 12 months (e.g. after-school science clubs, 4-H, scouts). Rural youth reported lower rates of participation in after-school science clubs and a greater desire to participate in after-school science programming than urban youth. Latino/a youth tend to have fewer informal science experiences than non-Latino/a youth, particularly in urban areas. There were few differences in informal science experiences between boys and girls, but in urban areas, girls report more science experiences than boys. Reported science experiences are overall higher in urban areas, yet youth with fewer resources (i.e. books in the home) have fewer informal science experiences overall. This study sheds new light on how socioeconomic status, gender, ethnicity, and geography interact with one another to shape youth science exposure and interest.
\end{abstract}

\section{INTRODUCTION}

With the exception of biology and veterinary science, most science, technology, engineering, and mathematics (STEM) fields are still over-represented by men (National Science Board, 2018; National Science Foundation, 2017). There is an increasing recognition of the importance of diversity in STEM and calls for increased proficiency, innovation, diversity, and involvement in the STEM workforce (Holdren et al., 2010; Østergaard et al., 2011; Page, 2008). Longitudinal studies show that early adolescence is a critical time in which interest in and identification with STEM declines and when gaps in science identities for underrepresented groups begin to emerge (Beede et al., 2011; Blue and Gann, 2008; Osborne et al., 2003; Sorge, 2007; Tan et al., 2013; Xie et al., 2015).

Science outreach programs that focus on girls and members of other historically underrepresented groups (e.g. rural, first generation, low socioeconomic status (SES), racial/ethnic minorities) hope to increase the number who will pursue science-related careers and thus diversify the biomedical and broader STEM workforce of the future. Little is known, however, about inequality in informal science access and participation for urban and rural youth at the intersection of SES. gender, and ethnicity. Few needs assessments have been conducted of school- or district-wide informal science opportunities that provide information across a range of underserved groups within and between schools. Such needs assessments could reveal gaps in science outreach efforts and also provide insights into how to better reach youth within their communities.

Understanding and increasing STEM proficiency, interest, identities, and inclusivity among adolescents has become a major goal of researchers, educators, policy makers and employers. Research studies and interventions have focused on formal education (e.g. Next Generation Science Standards) (Hayes et al., 2016; Lee et al., 2014; National Research Council, 2013) as well as on increasing the quantity and quality of informal learning opportunities (Barker et al., 2014; Fallik et al., 2013; Hirsch et al., 2010). In particular, increasing diversity has become a more prominent focus in helping to shape intervention efforts (Fallik et al., 
2013; Jayaratne et al., 2003; Liben and Coyle, 2014). One early outcome of research on youth STEM persistence is that recognition that a strong science identity is an indicator of a greater likelihood that youth will persist in science through high school, college and beyond. (Hill et al., 2017; Stets et al., 2017). Potential for adolescents to engage with science activities during out-of-school times is an important element for developing and maintaining a science identity (After-school Alliance, 2013).

Lifetime experiences with science vary by geography, social space, relationships, and other dimensions of lives (After-school Alliance, 2016; Archer et al., 2015; Miyake, 2017). Although scientific information is ubiquitous in the United States, in both formal (e.g. schools) and informal settings (e.g. clubs, after-school programs, museums, libraries, zoos, sports, fiction, television, and nature) (Barker et al., 2014; Bathgate et al., 2014; Cech, 2014), some groups are likely to have more science rich environments than others (DeWitt and Archer, 2017). Few studies have documented rates of participation in informal science among youth with different social locations (e.g. rural or urban, SES, girls and boys, Latino/a youth). It is an important first step to document how many and what kinds of informal science activities youth participate in, and to understand if and how access and participation is limited by social location.

Science education outreach seeks to identify youth who could most benefit from access to more authentic science. As part of a larger Science Education Partnership Award (SEPA) project, we conducted surveys in an urban middle school to identify students with the least informal science participation. We also collaborated with a researcher focused on rural youth who replicated and extended the original study. The goal of the current study is to explore whether there are identifiable subgroups who could benefit by having greater opportunities to participate in informal science activities. We use survey data from one rural and one urban middle school in a Midwest state to help understand perceived differences in self-reported informal science experiences. Our goal is to illuminate gaps in rates of participation in informal science by locale (rural/urban), family resources (measured by youth self-report of the estimated number of books in the home), gender (girls/boys), and ethnicity (non-Latino/a and Latino/a).

Urban and Rural Informal Science Resources and Access. The extent to which youth connect their daily experiences to science varies between rural and urban contexts (Avery, 2013; Basu and Barton, 2007; Buffington, 2016). Nearly $20 \%$ of children in public schools are enrolled in a rural district, (Buffington, 2016), and the number of children in rural areas is projected to grow more rapidly than those in urban areas (Johnson et al., 2014). Nationwide, half of school districts are rural and they tend to have lower fund- ing per student than most urban areas (Buffington, 2016; Chingos and Blagg, 2017; Johnson et al., 2014). The After School Alliance (2016) reports that youth in rural areas have less access to STEM role models and informal STEM learning resources such as science museums and zoos. Rural families often must travel considerable distances to access science resources that are available in urban communities. Urban researchers, however, may underestimate the capacity in rural areas to foster community connections and close links that can foster local science ecosystems (Avery, 2013; Dusenbery, 2010; Johnson et al., 2014; Schaefer et al., 2016). Additionally, rural youth may have experiences with agriculture, animal husbandry, and access to nature that connect them to science and engineering in their daily lives in ways that youth with urban experiences may not. Despite the prevalence of more local science attractions in urban centers, youth in urban areas may nevertheless face greater barriers to accessing informal science participation than rural youth due to factors including a lack of critical infrastructure in some high poverty urban neighborhoods/schools and social isolation (Barton, 2001; Dusenbery, 2010; Posner and Vandell, 1994; Sanderson and Richards, 2010).

\section{Socioeconomic Status, Gender and Ethnicity: Informal Science Resources and Access. In addition to geographic} location - rural versus urban - there is evidence that youth have unequal access to formal and informal science learning depending on socioeconomic status. Barriers for low income youth in urban settings may be similar to those in rural settings: inadequate transportation, lack of knowledge on availability of even low cost opportunities, and family time constraints due to heavy caretaker workloads and lack of affordable child care for younger siblings (Sanderson and Richards, 2010). Youth whose parents have a college degree, and particularly whose parents are themselves scientists, for example, have a distinct advantage over youth whose parents do not have similar knowledge or experience (Lareau, 2011; Weininger et al., 2015). Dabney et al. (2015) find that higher social class families (i.e. parents with more education) add more advantages for their children by taking their children to informal science experiences and encouraging their children to be interested in science. Their study shows that higher parental education is associated with more exposure to science occupations, hobbies, and classes as early as elementary school. Therefore social class inequality perpetuates when those who have given more to their children, helping science-rich families to get even richer (DeWitt and Archer, 2017). Every community is different however, in proximity to resources, in levels of inequality, and in concentration of poverty. As such, it is important that more research is done to understand the unique needs of every school and every community and to take into account location, and isolation of hard to reach populations in rural and urban areas. 
In the United States there is a gender conundrum in science: girls have higher science grades but are less likely to pursue degrees and careers in science (Buday et al., 2012; Else-Quest et al., 2013; Riegle-Crumb et al., 2006). Many factors may explain why girls may be less likely to persist in science including differences in science confidence, lack of female role models, or lack of parental or peer support, all which may impact whether girls see themselves as science people or not (Archer et al., 2013; Correll, 2004; Gauthier et al., 2017; Hill et al., 2017; Riegle-Crumb et al., 2006). Additionally, Lareau (2011) found that there were marked differences between boys and girls with respect to the types of after-school activities that they participated in, although the study did not focus on science-specific activities or on differences in geographic location. Across each of the different socioeconomic levels studied, she found a similar gendered pattern of extracurricular activity participation for boys and girls. Unfortunately, little research has been done on how gender norms and expectations differ in rural verses urban locations and how these might impact science career aspirations. There are indications, however, that girls in rural settings may have some educational advantages over boys, and that they may be more likely to enter non-traditional careers based on gender compared to their urban counterparts (Meece et al., 2014).

In addition to SES, gender, and geographic location, ethnic minority status is also associated with STEM participation. For example, although Latino/as make up approximately $16 \%$ of the U.S. workforce overall, they make up only $7 \%$ of the STEM workforce (Graf et al., 2018). Latino/a college students choose STEM majors at the same rate as other groups, but they are much less likely to graduate with a degree in a STEM field (Litow, 2008; Moller et al., 2015). Latinos are the second largest racial/ethnic group in the U.S. behind whites (Flores, 2017) and currently comprise 25\% of Americans under age 18 (U.S. Census Bureau, 2017), making them an important group for recruitment into STEM degrees and careers (Landivar, 2013). Latinos are also the fastest growing population in rural America (Lichter, 2012; Stepler and Lopez, 2016) and their rates of high school graduation are increasing so more Latino/ayouth have the opportunity to attend college than ever before (Ruetter, 2017).

Unfortunately, rural Latino/a youth have less access to advanced courses in K-12 schools and there are fewer after school programs in rural areas where many Latino/as live (Buffington, 2016; Leanard, 2016) which would potentially serve to get youth excited about STEM outside of the classroom (After-school Alliance, 2014, 2016). In a study using two national datasets, researchers looked at youth activity participation defined broadly (not science specific). They found that family income was the strongest predictor of overall activity participation, and Black and Latino/a youth were just as likely to participate in out of school time activ- ities as whites but participated with less intensity/frequency (Bouffard et al., 2006). In a recent review, Fredericks and Simpkins (2012) find that Latino/a youth participation in after-school activities in particular is lower overall than whites and depends more on socioeconomic status (SES). Simpkins et al. (2011), however, found in a previous study that country of origin and composition of friendship networks were more important predictors of participation than SES was among different Latino/a groups. Finally, although Latino/a have lower math and science achievement than whites, they have similar attitudes including how much they like math and science, how important they think math and science are, and how well they think they will do in math and science in the future (Else-Quest et al., 2013).

\section{PURPOSE}

The purpose of this study is explore and describe similarities and differences in science exposure in a rural and an urban middle school by level of family resources, gender, and, because of the composition of the sample, by Latino/a ethnic status. The current study focuses on self-reports of informal science activities among middle school youth in two schools (one urban and one rural). We compare youth on informal science exposure by SES, gender, and ethnicity within the urban and rural schools. Our comparative approach assumes that if there are patterns of difference (e.g. urban/rural, boys/ girls) then there are artificial structural (e.g. transportation, existence of the activity in the area), or social psychological (e.g. considered a "boy" or a "girl" activity), or socio-cultural (including discrimination) barriers to participation. We can thus see where there is equity (no differences between groups) and disparity (some groups have more participation than others) and thus can help identify unmet need for informal science outreach. We recognize that the schools we use do not represent all urban or rural schools. As a first step in examining how rural and urban communities may differ in informal science access and participation, we demonstrate a way to identify areas of focus or possible avenues of further study.

\section{METHODS}

Participants. We surveyed two middle schools in the same U.S. state- one in an urban Midwestern city and the other in a rural/remote town using the NCES classification (Flora, 2018; Provasnik et al., 2007). The urban middle school had a total of 686 students enrolled during the school year the survey was administered, while the rural school had 892 students enrolled. The urban middle school has Title I designation, which is an indication of higher poverty $(74 \%$ of the students receive free or reduced lunch). The urban school also has a 21 st Century Community Learning Center (CLC) 
that had science related after-school programming available every semester during the year the survey was administered. Federally funded, CLCs provide informal academic enrichment activities for students who attend schools with high-poverty enrollment through a variety of means and academic topic areas (Hammer and White, 2015). Multiple informal science learning institutions are located nearby the urban school, including a zoo and natural history museum. The rural middle school is not Title I eligible (i.e. not high enough proportion of students in poverty; $45 \%$ of youth who attend qualify for free or reduced lunch) and does not have a 21 st Century Community Learning Center. Half of the elementary schools in this rural remote town, however, do qualify as Title I and have Community Learning Centers where after-school science programming is incorporated. Besides 4-H, scouts, and an annual science fair, there are few formal after-school programs for middle-level students in the rural locale and no identified informal science institutions within a 100 -mile radius.

\section{PROCEDURE.}

This study uses data from web surveys conducted in an urban and a rural school. Data collection from the urban school was funded through an NIH Science Education Partnership Award (No. 1R25OD010506) and was part of a longitudinal study conducted in four waves over two consecutive school years at a middle school in a mid-sized Midwestern city. The current study reports data from Wave III administered in 2016. Data collection from the rural school was funded through an internal award at the researchers' institution. We administered a similar survey to the only middle school in a rural-remote town of approximately 20,000 residents in 2017. In both schools, students completed the surveys on computers in the students' science classrooms during a dedicated science class period. IRB approval was obtained with a waiver of signed parental consent (parents could opt their students out if they chose) and student assent was obtained prior to survey administration. A total of 419 urban and 619 rural students had complete data for the variables included in the analysis.

Measures. Race/Ethnic status (measuring vulnerability to racial inequality) was measured by the question: "What is your Race/Ethnicity? You can mark more than one answer." Due to small numbers of youth in some groups we focused on comparisons of groups that make up $10 \%$ or more of the population in both schools. In the case of these two schools we focus on differences between Latino/a and non-Latino/a youth in both rural and urban schools. These categories simplify the analyses but also potentially make it more difficult to find differences because some of the youth in the non-Latino/a group could have more disadvantages than white youth (e.g. Black youth are in the non-Latino/a group).

Grade level was measured by the question "What grade are you currently in?" and gender by "Are you a boy or a girl?" - the latter used to verify data from the school data already included in the online survey. To measure socioeconomic status youth were asked, "How many books do you have at home?" with "less than 10 books," "10-99 books," and " 100 or more books" as the response categories.

To measure informal science exposure youth were asked a series of questions about specific activities, including how often they visit public libraries, watch shows about science or nature, visit science museums, and visit zoos $(1=$ Never, $2=$ Once in a while, $3=$ Sometimes, $4=$ Often). Students were also asked if, in the last 12 months, they had attended a science after-school club, participated in other science activities (e.g. science fairs, summer camps), 4-H, and Boy Scouts or Girl Scouts (scouts). For those youth who attended either 4-H or scouts, they were also asked if any of their activities in those programs were science related. Finally, youth were asked how much they would like to join a new after school science club ( $1=$ Not at all interested, 2=Somewhat Interested, $3=$ Interested, 4=Very Interested).

\section{ANALYSIS}

We first looked at similarities and differences in informal science participation between the urban and rural middle school samples. We used SPSS version 22 and analyzed data using independent samples t-test and chi-square analyses. We then looked at differences by socioeconomic status, gender, and ethnicity using a combination of chi-square tests for proportions, and ANOVA to compare means for the multiple categories of books in the home by frequency of science activities on the 4-point ordinal scales. ${ }^{1}$ We use these two schools as case studies as examples of how to identify subgroups with potentially unmet need for informal science exposure. Although we conduct significance testing between rural and urban schools and within rural and urban schools by socioeconomic status, gender, and ethnicity, we caution directly generalizing these two case studies to other urban and rural school districts. We use significance tests as a heuristic indicator of larger and potentially more meaningful differences, but because we do not have random assignment or random samples, we do not meet the assumption of the significance tests. We discuss the possibilities of conducting similar studies in other communities to identify subgroups with unmet need for informal science experiences in the limitation section.

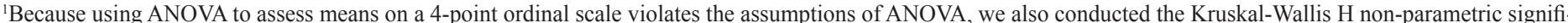

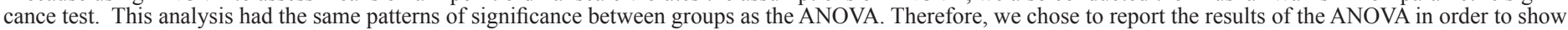
the mean differences instead of the median differences assessed in the non-parametric test. 


\section{RESULTS}

Table 1 provides descriptive statistics separately for the urban and rural school. Because of the very different social and historical contexts in each of these middle school populations, we see some large differences in ethnic/minority variation between schools. Specifically (categories are not mutually exclusive), in the urban school $24 \%$ reported Latino/a, 25\% reported Black or African American, 13\% reported Native American or American Indian, 5\% reported Asian, and $12 \%$ Other (this includes Native Hawaiian/Pacific Islanders). In the rural school 14\% were Latino/a, 5\% reported Black or African American, 4\% reported Native American

Table 1. Informal Science Self-Reported Participation Differences by Rural/Urban Middle Schools

\begin{tabular}{|c|c|c|c|c|c|c|}
\hline & \multicolumn{2}{|c|}{ Urban $(\mathrm{N}=419)$} & \multicolumn{3}{|c|}{$\begin{array}{c}\text { Rural } \\
(\mathrm{N}=619)\end{array}$} & \multirow[b]{2}{*}{ Range } \\
\hline & Mean/ Percent & SD & $\begin{array}{l}\text { Mean/ } \\
\text { Percent }\end{array}$ & SD & sig. & \\
\hline \multicolumn{7}{|l|}{ Race/Ethnicity ${ }^{a}$} \\
\hline Latino/a & $24 \%$ & & $14 \%$ & & $* * *$ & $0-1$ \\
\hline White & $52 \%$ & & $71 \%$ & & $* * *$ & $0-1$ \\
\hline African American & $25 \%$ & & $5 \%$ & & $* * *$ & $0-1$ \\
\hline $\begin{array}{l}\text { American Indian/ } \\
\text { Native American }\end{array}$ & $13 \%$ & & $4 \%$ & & $* * *$ & $0-1$ \\
\hline Asian & $5 \%$ & & $2 \%$ & & $* *$ & $0-1$ \\
\hline Other & $12 \%$ & & $11 \%$ & & $* * *$ & $0-1$ \\
\hline \multicolumn{7}{|l|}{ Gender } \\
\hline Girl & $48 \%$ & & $51 \%$ & & & $0-1$ \\
\hline \multicolumn{7}{|l|}{ Grade in School } \\
\hline 6 th & $32 \%$ & & $31 \%$ & & & $0-1$ \\
\hline 7 th & $28 \%$ & & $35 \%$ & & & $0-1$ \\
\hline 8 th & $40 \%$ & & $34 \%$ & & & $0-1$ \\
\hline How many books do you have at home? & & & & & $* * *$ & \\
\hline less than 10 books & $22 \%$ & & $14 \%$ & & & $0-1$ \\
\hline $11-100$ books & $54 \%$ & & $50 \%$ & & & $0-1$ \\
\hline more than 100 books & $24 \%$ & & $35 \%$ & & & $0-1$ \\
\hline \multicolumn{7}{|l|}{ How often do you ... } \\
\hline visit a public library? & 2.1 & 1 & 2.1 & 1 & & $1-4$ \\
\hline watch shows about science or nature? & 2.4 & 1 & 2.4 & 1 & & $1-4$ \\
\hline visit a science museum? & 1.7 & 0.7 & 1.7 & 0.8 & & $1-4$ \\
\hline visit a zoo? & 2.4 & 0.9 & 2.5 & 0.9 & & $1-4$ \\
\hline $\begin{array}{l}\text { Have you done a science after school club in the } \\
\text { last year? }\end{array}$ & $21 \%$ & & $4 \%$ & & $* * *$ & $0-1$ \\
\hline $\begin{array}{l}\text { Have you done any other science activities in } \\
\text { the last year? }\end{array}$ & $13 \%$ & & $12 \%$ & & $* *$ & $0-1$ \\
\hline Have you participated in $4 \mathrm{H}$ for the last year? & $7 \%$ & & $9 \%$ & & & $0-1$ \\
\hline $\begin{array}{l}\text { Were any of your } 4 \mathrm{H} \text { activities related to sci- } \\
\text { ence? }\end{array}$ & $61 \%$ & & $43 \%$ & & + & $0-1$ \\
\hline $\begin{array}{l}\text { Have you participated in boy scouts or girl } \\
\text { scouts in the last year? }\end{array}$ & $12 \%$ & & $9 \%$ & & & $0-1$ \\
\hline $\begin{array}{l}\text { Were any of your BS/GS activities related to } \\
\text { science? }\end{array}$ & $68 \%$ & & $70 \%$ & & & $0-1$ \\
\hline $\begin{array}{l}\text { How much would you like to join a new after- } \\
\text { school science club? }\end{array}$ & 1.9 & 1 & 2.2 & 1.1 & $* * *$ & $1-4$ \\
\hline
\end{tabular}

${ }^{a}$ Race/Ethnic categories are not mutually exclusive $+p<.10,{ }^{*} p<.05, * * p<.01, * * *<p>.001$ 


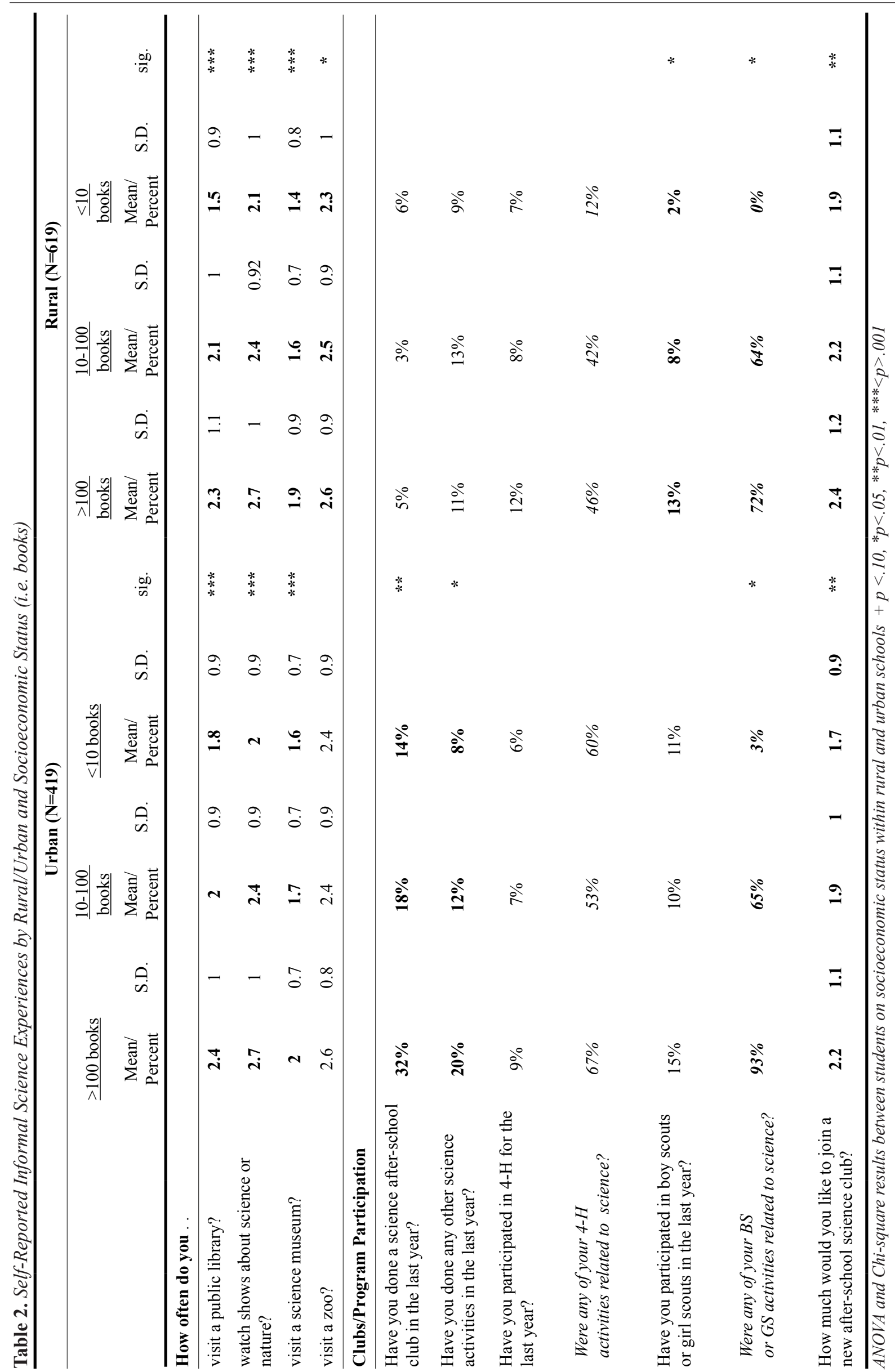


or American Indian heritage, 2\% reported Asian and 11\% Other (this includes Native Hawaiian/Pacific Islanders). Therefore, unlike some national studies in which more rural youth are Latino/a, for this study more of the urban youth are Latino/a. Both schools are almost half each girls and boys. More youth in the urban school had fewer than 10 books $(14 \%)$ and more youth in the rural school had more than 100 books (35\%) indicating a higher poverty rate at the urban school. The higher rate of poverty in the urban school is consistent with the school qualifying as a Title I-A recipient.

Rates of self-reported participation in the informal science activities were similar for youth in the urban and rural schools with one exception. Twenty-one percent of youth in the urban school had said they had participated in an after-school science club in the last year, and only $4 \%$ of rural youth reported this $(\mathrm{p}<.001)$. Additionally, the mean desire to join a new after-school science club was slightly higher in the rural school (2.2) than the urban school (1.9); this was the largest difference for the measures with four response options. We were surprised, however, that frequency of visiting a zoo (2.4/2.5 or between "once in a while" and "sometimes") and visiting a science museum (1.7 or slightly less than "once in a while") were similar for urban and rural youth given differences in distance from a zoo science museum for youth in the rural community.

In Table 2 we divide the sample between urban and rural schools and we assess difference in informal science experiences for youth with different family resources. We find that overall, youth who report fewer than ten books in the home report less frequent visits to public libraries, less frequency of watching nature shows, and fewer visits to science museums, and that these patterns by socioeconomic status and level of engagement were similar across both schools. We did not find a difference in frequency of visiting zoos in urban areas by the number of books in the home, however we did find that youth reporting fewer books in the home in rural areas reported visiting zoos less frequently.

In the urban, but not the rural, school we found that the youth with fewer books were less likely to report engaging in after school science or other science activities in the last year. Students with the most resources in the urban areas reported greater participation. In the rural areas, however, even the youth with the most resources reported lower rates of participation than most groups in the urban school. We did not find significant difference by socioeconomic status in 4-H participation or in science related content in either location. Very few youth with fewer than ten books in the home reported participating in scouts. Youth who reported a greater number of books in their home were much more likely to report that scouting activities were related to science than youth with fewer books. Finally, in both urban and rural schools, youth who reported fewer books in their home were less likely to indicate interest in joining a new after-school science club.

In Table 3, we divide the samples into rural and urban schools by gender to explore patterns in participation between boys and girls. Overall, girls were more likely than boys to visit a library, and this was more evident in girls from rural schools. In rural schools only, boys were more likely to report watching shows related to science or nature, while girls were more likely to report visiting a zoo. In the rural schools, girls were also slightly more likely to participate in 4-H, although 4-H content was similar for boys and girls in both urban and rural samples. Finally, rural girls had the highest desire to join an after-school science club (2.3) followed by rural boys (2.1), urban girls (2.0) and urban boys (1.8). Girls in urban schools were more likely than boys to report participating in other science related activities, and they were more likely to report participating in scouts. Reports of science content in rural or urban samples did not differ between boys and girls.

In Table 4, we divide the sample between rural and urban schools and we assess difference in informal science experiences by Latino/a status. Overall, there are few significant differences between non-Latino/a youth and Latino/a youth. Fewer Latino/a than non-Latino/a reported visiting a science museum at the rural school (1.5 vs. $1.7, \mathrm{p}<.10)$, but there were no differences between groups within the urban school (both 1.7). In the urban school, fewer Latino/a than non-Latino/a youth report participating in 'other science activities' in the last year $(15 \%$ vs. $8 \%, p<.05)$. In the rural school "other science activities" do not differ by ethnicity. Additionally, in the urban but not the rural school Latino/a and non-Latino/a students reported different levels of participation in scouts as well as different levels of science content in their scouts group. In the urban school, $14 \%$ of non-Latino/a youth and only $5 \%$ of non-Latino/a youth reported participating in scouts in the last year. Among those who participated in scouts, non-Latino/a students reported more science content than Latino/a scouts. We cannot know if the difference is due to recognizing science content as such or if Latino/a and non-Latino/a youth were in different scouts groups. Other studies have also shown that scouts participation for Latino/a youth is lower than for non-Latino/a youth (Bouffard et al., 2006).

\section{STUDY LIMITATIONS}

With a sample of just one urban and one rural school, we cannot generalize our results to all urban and rural communities. Each community and school offers unique opportunities and barriers with respect to out-of-school science programming, venues, and resources. Our findings, however, are a first step in identifying possible patterns that may exemplify differences between youth in rural and urban locations and access to informal science experiences. 
Table 3. Self-Reported Informal Science Experiences by Rural/Urban and gender

\begin{tabular}{|c|c|c|c|c|c|c|c|c|c|c|}
\hline \multirow[b]{3}{*}{ How often do you... } & \multicolumn{5}{|c|}{ Urban $(\mathrm{N}=419)$} & \multicolumn{5}{|c|}{ Rural $(\mathrm{N}=619)$} \\
\hline & Boy & & $\underline{\text { Girl }}$ & & & Boy & & $\underline{\text { Girl }}$ & & \\
\hline & $\begin{array}{l}\text { Mean/ } \\
\text { Percent }\end{array}$ & S.D. & $\begin{array}{l}\text { Mean/ } \\
\text { Percent }\end{array}$ & S.D & sig. & $\begin{array}{l}\text { Mean/ } \\
\text { Percent }\end{array}$ & S.D. & $\begin{array}{l}\text { Mean/ } \\
\text { Percent }\end{array}$ & S.D. & sig. \\
\hline visit a public library? & 2 & 1 & 2.2 & 1 & + & 1.9 & 0.9 & 2.2 & 1.1 & $* * *$ \\
\hline watch shows about science or nature? & 2.4 & 1 & 2.3 & 0.9 & & 2.5 & 1 & 2.4 & 0.9 & $* * *$ \\
\hline visit a science museum? & 1.7 & 0.7 & 1.7 & 0.8 & & 1.7 & 0.8 & 1.7 & 0.8 & \\
\hline visit a zoo? & 2.4 & 0.8 & 2.5 & 0.9 & & 2.4 & 0.9 & 2.6 & 0.9 & $* * *$ \\
\hline \multicolumn{11}{|l|}{ Clubs/Program Participation } \\
\hline $\begin{array}{l}\text { Have you done a science after school } \\
\text { club in the last year? }\end{array}$ & $20 \%$ & & $21 \%$ & & & $4 \%$ & & $4 \%$ & & \\
\hline $\begin{array}{l}\text { Have you done any other science activi- } \\
\text { ties in the last year? }\end{array}$ & $11 \%$ & & $16 \%$ & & $*$ & $12 \%$ & & $11 \%$ & & \\
\hline $\begin{array}{l}\text { Have you participated in } 4 \mathrm{H} \text { for the last } \\
\text { year? }\end{array}$ & $7 \%$ & & $7 \%$ & & & $8 \%$ & & $11 \%$ & & + \\
\hline $\begin{array}{l}\text { Were any of your } 4 H \text { activities related } \\
\text { to science? }\end{array}$ & $53 \%$ & & $64 \%$ & & & $46 \%$ & & $38 \%$ & & \\
\hline $\begin{array}{l}\text { Have you participated in boy scouts or } \\
\text { girl scouts in the last year? }\end{array}$ & $8 \%$ & & $15 \%$ & & $*$ & $11 \%$ & & $7 \%$ & & + \\
\hline $\begin{array}{l}\text { Were any of your } B S \text { or } G S \text { activities } \\
\text { related to science? }\end{array}$ & $74 \%$ & & $55 \%$ & & & $62 \%$ & & $73 \%$ & & \\
\hline $\begin{array}{l}\text { How much would you like to join a new } \\
\text { after-school science club? }\end{array}$ & 1.8 & 1 & 2 & 1 & + & 2.1 & 1.1 & 2.3 & 1.1 & $*$ \\
\hline
\end{tabular}

Independent Sample t-tests between girls and boys within rural and urban schools. $+p<.10, * p<.05, * * p<.01, * * * p>.001$

All the data were from student self-reports about their experiences and therefore depend upon youth ability to recognize what is "science" and what is not. Additionally, the questions asked youth to remember their activities over a year's time. Future studies could use verifiable data such as participation records or triangulate information from multiple sources to enhance accuracy. Such an approach could also provide more detailed information about the types and quality of informal activities, level of participation, and other salient factors about youth access and engagement.

\section{DISCUSSION AND IMPLICATIONS FOR FUTURE RESEARCH}

Science education outreach seeks to identify youth who could most benefit from access to more science. We conducted surveys in an urban and a rural middle school to identify students with the least informal science participation. The goal was to identify subgroups of youth least served by existing informal science activities and thus most likely to benefit from informal science outreach activities.

The patterns of reported informal science experiences were similar for many of the informal science activities in the urban and rural school. In both the rural and urban schools, informal science opportunities are positively linked to higher levels of family resources, as measured youth reported number of books in the home. Echoing other researchers' findings (DeWitt and Archer, 2017; Fredricks and Simpkins, 2012), youth in our sample with the fewest books in their homes have significantly less participation in informal science. Future studies can help illuminate what kinds of informal science opportunities are accessed by low-income youth, and how to make those opportunities more abundant, appealing and available.

Rural and urban settings differed primarily in the specific types of informal opportunities that students participated in. Overall, there was less participation in informal science activities among rural compared to urban youth. Urban students, for example, participate significantly more than rural students in after-school science; in contrast rural youth expressed a greater desire to join after-school science clubs. The urban school students in our survey benefited by the availability of after-school programs provided through the 21 st Century Community Learning Centers and other community partnerships. While rural youth expressed significantly more interest in wanting to join an after-school science club, but they do not have after-school programming in the local middle school, and rural communities lack the re- 
Table 4. Self-Reported Informal Science Experiences by Rural/Urban and Ethnicity

\begin{tabular}{|c|c|c|c|c|c|c|}
\hline & \multicolumn{2}{|c|}{ Urban $(\mathrm{N}=419)$} & \multicolumn{4}{|c|}{ Rural $(\mathrm{N}=619)$} \\
\hline & $\underline{\text { Non-Latino/a }}$ & $\underline{\text { Latino/a }}$ & & Non-Latino/a & $\underline{\text { Latino/a }}$ & \\
\hline How often do you ... & Mean/ Percent & Mean/ Percent & sig. & Mean/ Percent & Mean/ Percent & sig. \\
\hline visit a public library? & 2.1 & 1.9 & & 2.1 & 2.1 & \\
\hline watch shows about science or nature? & 2.4 & 2.3 & & 2.4 & 2.5 & \\
\hline visit a science museum? & 1.7 & 1.7 & & 1.7 & 1.5 & + \\
\hline visit a zoo? & 2.4 & 2.6 & & 2.5 & 2.4 & \\
\hline \multicolumn{7}{|l|}{ Clubs/Program Participation } \\
\hline Have you done a science after school club in the last year? & $22 \%$ & $18 \%$ & & $4 \%$ & $3 \%$ & \\
\hline $\begin{array}{l}\text { Have you done any other science activities in the last } \\
\text { year? }\end{array}$ & $15 \%$ & $8 \%$ & + & $12 \%$ & $13 \%$ & \\
\hline Have you participated in $4 \mathrm{H}$ for the last year? & $8 \%$ & $4 \%$ & & $9 \%$ & $9 \%$ & \\
\hline Were any of your $4 H$ activities related to science? & $60 \%$ & $50 \%$ & & $40 \%$ & $50 \%$ & \\
\hline $\begin{array}{l}\text { Have you participated in boy scouts or girl scouts in the } \\
\text { last year? }\end{array}$ & $14 \%$ & $5 \%$ & $*$ & $9 \%$ & $11 \%$ & \\
\hline Were any of your BS or GS activities related to science? & $70 \%$ & $40 \%$ & $*$ & $70 \%$ & $50 \%$ & \\
\hline $\begin{array}{l}\text { How much would you like to join a new after-school } \\
\text { science club? }\end{array}$ & 1.9 & 1.9 & & 2.2 & 2.1 & $*$ \\
\hline
\end{tabular}

Independent Sample t-tests between Latino/a and non-Latino/a youth within rural and and urban schools. $+p<.10, * p<.05, * * p<.01, * * *<p>.001$

sources to provide quality after-school content after-school (Hirsch et al., 2010; Holstead and King, 2011). On the other hand, science outreach experts and researchers in formal and informal education may not always recognize assets in rural communities (Avery, 2013; Brown and Schafft, 2011). These results offer a clear action item for informal science educators - to focus on the development and implementation of quality, sustainable, after-school science learning opportunities for rural youth.

Despite our observed differences in participation in certain types of informal science activities between rural and urban youth, it can be argued that access to internet resources, television, and other science-oriented clubs and camps ameliorate any disadvantages in science learning opportunities. Furthermore, rural youth may have more opportunities than urban youth to interact with agriculture, animal husbandry, and natural settings that provide exposure to scientific activities and technology in contexts not available to urban youth. The extent to which they view these activities as science related is unknown. It is important to recognize that youth vary in discovery orientations or propensities to observe patterns or to recognize science in their experiences, and that they may lack a diversity of science role models for understanding career options. Our understanding of the extent to which youth connect their rural and urban experiences to science learning or understanding, and the best practices for guiding them in making these connections, is an important direction for additional research.

Latino/a youth from our rural, but not urban, locales reported fewer visits to museums or science centers than non-Latino/a youth. This suggests that underrepresented minority youth in rural settings may experience additional challenges regarding access to informal science learning opportunities. Despite this difference, however, urban (but not rural) Latino/a youth were less likely to report participating in other science activities than non-Latino/a youth. We are hesitant to draw too many conclusions from these data as we only focused on a single rural and urban middle school, each with a relatively low proportion of Latino/a students $(<25 \%)$. Nonetheless, these preliminary data demonstrate a need for more rigorous assessment of differences among underrepresented minorities from rural and urban locales.

Our study provides an assessment of rural and urban youth participation in informal science learning opportunities. Most youth, for example, are curious, enjoy exploring, and thus have high levels of what Hill et al. (2018) call "discovery orientation." Yet only some youth translate high discovery orientation into high science identities. The factors that influence the trajectory from discovery orientation to high science identity and finally to science career aspirations is only beginning to be understood. Understanding how gender, socioeconomic status, ethnicity, and informal science participation intersect with one another can strengthen science outreach efforts to be more effective at encouraging all youth to engage with science. SEPA projects are particularly well positioned to provide science knowledge and skills to youth with the fewest resources in their homes. The informal science activities and resources that many SEPA projects 
provide can help improve the science learning opportunities available to youth from low financial resource families.

The questions raised in this study require future research to answer the long term implications of differences in science exposure and engagement for science identity, science persistence, and understanding of the process of science. Further study is needed to clarify how new initiatives reinforce science identities, interests, and career aspirations. How, for example, do youth's perceptions of what is science and what is not influence the effectiveness of science outreach programs? How important is it for youth to know how science is relevant to their daily lives? What are the differential impacts of science outreach programs on youth based on geography, ethnicity, and financial stability? In particular, how can science outreach efforts mostly effectively impact girls and youth of color? Future studies can begin to establish a framework for how out-of-school science engagement can have the greatest impact on furthering the participation of all youth in science.

\section{AUTHOR INFORMATION Corresponding Author}

Patricia Wonch Hill, phill3@unl.edu. Methodology and Evaluation Research Core Facility, University of NebraskaLincoln (NE).

\section{Author Contributions}

The manuscript was written through contributions of all authors. All authors have given approval to the final version of the manuscript.

\section{FUNDING SOURCES}

Biology of Human is funded by the National Institutes of Health through the Science Education Partnership Award (SEPA) Grant No. 1R25OD010506.

\section{REFERENCES}

Afterschool Alliance. (2013). Defining Youth Outcomes for STEM Learning in Afterschool. Afterschool Alliance.org.

Afterschool Alliance. (2014). America after 3PM: Afterschool programs in demand. Washington, DC: Afterschool Alliance.

Afterschool Alliance. (2016). The Growing Importance of Afterschool in Rural Communities (America After 3pm Special Report)

Archer, L., Dawson, E., DeWitt, J., Seakins, A., and Wong, B. (2015). "Science capital": A conceptual, methodological, and empirical argument for extending bourdieusian notions of capital beyond the arts. Journal of Research in Science Teaching, 52(7), 922-948.
Archer, L., DeWitt, J., Osborne, J., Dillon, J., Willis, B., and Wong, B. (2013). 'Not girly, not sexy, not glamorous': primary school girls' and parents' constructions of science aspirations 1. Pedagogy, Culture and Society, 21(1), 171-194. https://doi.org/10.1080/14681366.2012.748676

Avery, L. M. (2013). Rural science education: Valuing local knowledge. Theory Into Practice, 52(1), 28-35.

Barker, B., Larson, K., and Krehbiel, M. (2014). Bridging Formal and Informal Learning Environments. Journal of Extension, 52(5), 5-5.

Barton, A. C. (2001). Science education in urban settings: Seeking new ways of praxis through critical ethnography. Journal of Research in Science Teaching, 38(8), 899-917.

Basu, S. J., and Barton, A. C. (2007). Developing a sustained interest in science among urban minority youth. Journal of Research in Science Teaching, 44(3), 466-489.

Bathgate, M. E., Schunn, C. D., and Correnti, R. (2014). Children's motivation toward science across contexts, manner of interaction, and topic. Science Education, 98(2), 189-215.

Beede, D., Julian, T., Langdon, D., McKittrick, G., Khan, B., and Doms, M. (2011). Women in STEM: A Gender Gap to Innovation. ESA Issue Brief\# 04-11. US Department of Commerce. Retrieved from http://eric.ed.gov/?id=ED523766

Blue, J., and Gann, D. (2008). When do girls lose interest in math and science? Science Scope, 32(2), 44-47.

Bouffard, S. M., Wimer, C., Caronongan, P., Little, P., Dearing, E., and Simpkins, S. D. (2006). Demographic differences in patterns of youth out-of-school time activity participation. Journal of Youth Development, 1(1), 24-40. https://doi. org/10.5195/jyd.2006.396

Brown, D. L., and Schafft, K. A. (2011). Rural people and communities in the 21st century: Resilience and transformation. Polity. Retrieved from https://books.google. com/books?hl=en \&lr=\&id=x5L-O6T9I0MC\&oi=fnd\&pg $=$ PR $1 \& d q=$ Brown + and + Schafft $+2011 \&$ ots $=K-$ F U O 7 O O y W x \& s i g = P z K 9 fk G V 4 R 1 x J G Y W3oRXVoYEj5Q

Buday, S. K., Stake, J. E., and Peterson, Z. D. (2012). Gender and the choice of a science career: The impact of social support and possible selves. Sex Roles, 66(3-4), 197-209. https:// doi.org/10.1007/s11199-011-0015-4

Buffington, P. (2016). Closing STEM Education Opportunity Gaps for Rural Students. Retrieved October 13, 2017, from http://ltd.edc.org/closing-STEM-education-opportunity-gaps-rural

Cech, E. A. (2014). Embed social awareness in science curricula. Nature, 505(7484), 477-478.

Chingos, M. M., and Blagg, K. (2017). Do Poor Kids Get Their Fair Share of School Funding? Retrieved from http://www. urban.org/sites/default/files/publication/90586/school_ funding_brief.pdf

Correll, S. J. (2004). Constraints into preferences: Gender, status, and emerging career aspirations. American Sociological Review, 69(1), 93-113. 
DeWitt, J., and Archer, L. (2017). Participation in informal science learning experiences: the rich get richer? International Journal of Science Education, Part B, 0(0), 1-18. https:// doi.org/10.1080/21548455.2017.1360531

Dusenbery, P. (2010). STAR Library Education Network: a handson learning programfor libraries and their communities. In AGU Fall Meeting Abstracts.

Else-Quest, N. M., Mineo, C. C., and Higgins, A. (2013). Math and science attitudes and achievement at the intersection of gender and ethnicity. Psychology of Women Quarterly, 37(3), 293-309. https://doi.org/10.1177/0361684313480694

Fallik, O., Rosenfeld, S., and Eylon, B.-S. (2013). School and outof-school science: a model for bridging the gap. Studies in Science Education, 49(1), 69-91. https://doi.org/10.1080/ 03057267.2013 .822166

Flora, C. B. (2018). Rural communities: Legacy+ change. Routledge.

Flores, A. (2017, September 18). How the U.S. Hispanic population is changing. Retrieved September 5, 2018, from http:// www.pewresearch.org/fact-tank/2017/09/18/how-the-u-shispanic-population-is-changing/

Fredricks, J. A., and Simpkins, S. D. (2012). Promoting positive youth development through 0rganized after-school activities: Taking a closer look at participation of ethnic minority youth. Child Development Perspectives, 6(3), 280-287. https://doi.org/10.1111/j.1750-8606.2011.00206.x

Gauthier, G. R., Hill, P. W., McQuillan, J., Spiegel, A. N., and Diamond, J. (2017). The potential scientist's dilemma: How the masculine framing of science shapes friendships and science job aspirations. Social Sciences, 6(1), 14. https:// doi.org/10.3390/socsci6010014

Graf, N., Fry, R., and Funk, C. (2018, January 9). 7 facts about the STEM workforce. Retrieved September 5, 2018, from http://www.pewresearch.org/fact-tank/2018/01/09/7facts-about-the-stem-workforce/

Hammer, P. C., and White, L. J. (2015). 21st Century Community Learning Centers: A Descriptive Evaluation for 20132014. West Virginia Department of Education. Retrieved from https://eric.ed.gov/?id=ED569701

Hayes, K. N., Lee, C. S., DiStefano, R., O'Connor, D., and Seitz, J. C. (2016). Measuring science instructional practice: A survey tool for the age of NGSS. Journal of Science Teacher Education, 27(2), 137-164.

Hill, P. W., McQuillan, J., Spiegel, A. N., and Diamond, J. (2018). Discovery orientation, cognitive schemas, and disparities in science identity in early adolescence. Sociological Perspectives, 61(1). 99-125. 073112141772477. https://doi. org/10.1177/0731121417724774

Hill, P. W., McQuillan, J., Talbert, E., Spiegel, A., Gauthier, G. R., and Diamond, J. (2017). Science possible selves and the desire to be a scientist: Mindsets, gender bias, and confidence during early adolescence. Social Sciences, 6(2), 55. https://doi.org/10.3390/socsci6020055

Hirsch, B. J., Mekinda, M. A., and Stawicki, J. (2010). More than attendance: The importance of after-school program quality. American Journal of Community Psychology, 45(3-4), 447-452. https://doi.org/10.1007/s10464-010-9310-4
Holdren, J. P., Lander, E. S., and Varmus, H. (2010). Prepare and inspire: K-12 education in science, technology, engineering, and math (STEM) for America's future. Executive Report). Washington, DC: President's Council of Advisors on Science and Technology.

Holstead, J., and King, M. H. (2011). High-Quality 21st century community learning centers: academic achievement among frequent participants and non-participants. Journal of Education for Students Placed at Risk (JESPAR), 16(4), 255-274. https://doi.org/10.1080/10824669.2011.611045

Jayaratne, T. E., Thomas, N. G., and Trautmann, M. (2003). Intervention program to keep girls in the science pipeline: Outcome differences by ethnic status. Journal of Research in Science Teaching, 40(4), 393-414.

Johnson, J., Showalter, D., Klein, R., and Lester, C. (2014). Why Rural Matters 2013-2014: The Condition of Rural Education in the 50 States. Rural School and Community Trust.

Landivar, L. C. (2013). Disparities in STEM employment by sex, race, and Hispanic origin. Education Review, 29(6), 911922.

Lareau, A. (2011). Unequal childhoods: Class, race, and family life. Univ of California Press. Retrieved from https:// books.google.com/books?hl=en\&lr=\&id=JuQuoPKMPF4C\&oi $=$ fnd\&pg $=$ PP1\&dq $=$ lareau + unequal + child hoods\&ots=up4bwM2BqP\&sig=K1MRYCZ_kBF_N5sdovQo7tD-ws4

Leanard, K. (2016, May 19). Building a Latino Wave in STEM. US News \& World Report. Retrieved from https://www. usnews.com/news/articles/2016-05-19/building-a-latinowave-in-stem

Lee, O., Miller, E. C., and Januszyk, R. (2014). Next generation science standards: All standards, all students. Journal of Science Teacher Education, 25(2), 223-233.

Liben, L. S., and Coyle, E. F. (2014). Developmental Interventions to Address the STEM Gender Gap: Exploring Intended and Unintended Consequences. In Advances in Child Development and Behavior (Vol. 47, pp. 77-115). Elsevier. Retrieved from http://linkinghub.elsevier.com/retrieve/pii/ S0065240714000111

Lichter, D. T. (2012). Immigration and the new racial diversity in rural America. Rural Sociology, 77(1), 3-35. https://doi. org/10.1111/j.1549-0831.2012.00070.x

Litow, S. (2008). A silent crisis: The underrepresentation of Latinos in STEM careers. Education Week, 27, 1-2.

Meece, J. L., Askew, K. J. S., Agger, C. A., Hutchins, B. C., and Byun, S. (2014). Familial and economic influences on the gender-related educational and occupational aspirations of rural adolescents. Journal of Educational and Developmental Psychology, 4(1), 238-257. https://doi. org/10.5539/jedp.v4n1p238

Miyake, S. (2017). Learning science in informal contexts. In Science Education (pp. 431-442). SensePublishers, Rotterdam. Springer.

Moller, S., Banerjee, N., Bottia, M. C., Stearns, E., Mickelson, R. A., Dancy, M., Wright, E., and Valentino, L. (2015). Moving Latino/a students into STEM majors in college: The role of teachers and professional communities in secondary schools. Journal of Hispanic Higher Education, 14(1), 
$3-33$.

National Research Council. (2013). Next Generation Science Standards: For states, by states.

National Science Board. (2018). Science and Engineering Indicators 2018. Arlington, VA: National Science Foundation. Retrieved from http://www.nsf.gov/statistics/seind18/

National Science Foundation. (2017). Women, Minorities, and Persons with Disabilities in Science and Engineering: 2017 (No. Special Report NSF 17-310). Arlington, VA. Retrieved from https:/www.nsf.gov/statistics/2017/ nsf17310/static/downloads/nsf17310-digest.pdf

Osborne, J., Simon, S., and Collins, S. (2003). Attitudes towards science: A review of the literature and its implications. International Journal of Science Education, 25(9), 10491079. https://doi.org/10.1080/0950069032000032199

Østergaard, C. R., Timmermans, B., and Kristinsson, K. (2011). Does a different view create something new? The effect of employee diversity on innovation. Research Policy, 40(3), 500-509. https://doi.org/10.1016/j.respol.2010.11.004

Page, S. E. (2008). The Difference: How the Power of Diversity Creates Better Groups, Firms, Schools, and Societies (New edition with a New preface by the author edition). Princeton, NJ: Princeton University Press.

Posner, J. K., and Vandell, D. L. (1994). Low-income children's after-school care: Are there beneficial effects of after-school programs? Child Development, 65(2), 440-456.

Provasnik, S., KewalRamani, A., Coleman, M. M., Gilbertson, L., Herring, W., and Xie, Q. (2007). Status of Education in Rural America. NCES 2007-040. National Center for Education Statistics.

Riegle-Crumb, C., Farkas, G., and Muller, C. (2006). The role of gender and friendship in advanced course taking. Sociology of Education, 79(3), 206-228.

Ruetter, H. (2017). A growing population. The Grand Island Independent. Retrieved from https://www.theindependent. $\mathrm{com} /$ news/local/a-growing-population/article_1172b08ce2d2-11e7-99c9-63f2b1b9726e.html

Sanderson, R. C., and Richards, M. H. (2010). The after-school needs and resources of a low-income urban community: surveying youth and parents for community change. American Journal of Community Psychology, 45(3-4), 430-440. https://doi.org/10.1007/s10464-010-9309-x

Schaefer, A. P., Mattingly, M. J., and Johnson, K. M. (2016). Child Poverty Higher and More Persistent in Rural America. University of New Hampshire Carsey School of Public Policy, (97), 8.

Simpkins, S. D., O’Donnell, M., Delgado, M. Y., and Becnel, J. N. (2011). Latino adolescents' participation in extracurricular activities: How important are family resources and cultural orientation? Applied Developmental Science, 15(1), 37-50.

Sorge, C. (2007). What Happens? Relationship of age and gender with science attitudes from elementary to middle school. Science Educator, 16(2), 33-37.
Stepler, R., and Lopez, M. H. (2016, September 8). U.S. Latino Population Growth and Dispersion Has Slowed Since Onset of the Great Recession. Retrieved September 5, 2018, from http://www.pewhispanic.org/2016/09/08/latino-population-growth-and-dispersion-has-slowed-since-the-onset-of-the-great-recession/

Stets, J. E., Brenner, P. S., Burke, P. J., and Serpe, R. T. (2017). The science identiandy and entering a science occupation. Social Science Research, 64, 1-14. https://doi.org/10.1016/j. ssresearch.2016.10.016

Tan, E., Calabrese Barton, A., Kang, H., \& O’Neill, T. (2013). Desiring a career in STEM-related fields: How middle school girls articulate and negotiate identities-in-practice in science. Journal of Research in Science Teaching, 50(10), 1143-1179. https://doi.org/10.1002/tea.21123

U.S. Census Bureau. (2017). Race for Results: 2017 Policy Report (Annie E. Casey Foundation). Baltimore, MD: Population Reference Bureau.

Weininger, E. B., Lareau, A., and Conley, D. (2015). What money doesn't buy: class resources and children's participation in organized extracurricular activities. Social Forces, sov071.

Xie, Y., Fang, M., and Shauman, K. (2015). STEM Education. Annual Review of Sociology, (0). Retrieved from http://www.annualreviews.org/doi/pdf/10.1146/annurev-soc-071312-145659 